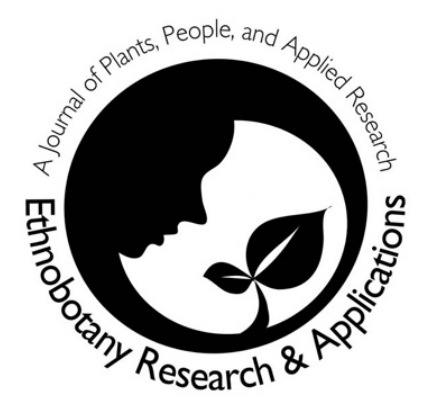

\title{
Ecology and Ethnobotany in and around Api Nampa Conservation Area (ANCA), Darchula, Nepal
}

Dirgha R. Joshi, Ripu M. Kunwar, Youba R. Pokharel and Man D. Bhatt

\section{Correspondence}

Dirgha R. Joshi ${ }^{1}$, Ripu M. Kunwar ${ }^{2}$, Youba R. Pokharel ${ }^{3}$ and Man D. Bhatt ${ }^{*}$

${ }^{1,4}$ Department of Botany Siddhanath Science Campus, Tribhuvan University, Mahendranagar, Nepal

${ }^{2}$ Ethnobotanical Society of Nepal, Kathmandu, Nepal

${ }^{3}$ Ministry of Forests and Environment, Kathmandu, Nepal

*Corresponding Authors: kawtar. bhattmdrp@gmail.com

Ethnobotany Research \& Applications 22:49 (2021)

\section{Research}

\begin{abstract}
Background. Far-Western mountainous Region of Nepal is a rich source of floral diversity and medicinal plants. The latter is frequently being used in traditional healing systems in the region. In the present study, we aimed to document richness and diversity of flowering plant species including medicinal species and their indigenous uses in Api Nampa Conservation Area (ANCA) of Darchula district, Far Western Nepal. To be precise, we explored the detail ethnobotanical accounts of Hippophae species of the area.
\end{abstract}

Methods. Fieldwork for this study was carried out twice in July 2019 and July 2020. Ghajir Kshetti, Khirsha and Lamthing villages of eastern ANCA (considered as a protected site, government managed) and Patha, Ranghadi, Kantai and Batheldhunga villages of northern ANCA (considered as community-managed site) were sampled. A total of ten quadrats each measuring $10 \mathrm{~m} \times 10 \mathrm{~m}$ size in each site was laid to inventory the species and analyze the ecological traits. For ethnobotanical assessment, two field observations were made and 20 people, representing male, female, senior citizens were interviewed. Supplementary information was collected during informal group discussions held in the villages and in district center.

Results. We recorded 76 plant species including Hippophae salicifolia in two different study sites of ANCA, Darchula. The species belonged to 33 families and 62 genera. The dominant plant families were Pinaceae, Rosaceae, Poaceae, Ericaceae and Asteraceae. The comparative assessment showed that the protected site has greater number plant species 60 (78.94\%) whereas the northern ANCA site has only 37 (48.68\%) species. The highest IVI (26.95) was recorded for Hippophae salicifolia and minimum (2.37) for Daphne papyracea. As dominant, the Hippophae salicifolia was frequently used traditionally for primary health care, local livelihood, nutrition, cosmetics, and environmental management. Out of 76, 65 species were used for ethnobotany and 11 species for ethnomedicine.

Conclusions. Protected ANCA site is rich in plant species. The site and whole ANCA are dominated by useful plant species such as Hippophae salicifolia, Alnus nepalensis, Elaeagnus parvifolia, Girardiania diversifolia, Ilex excelsa, Juglans regia, etc. This study contributes to the wealth of medicinal plants and ethnobotany of ANCA, Darchula. Conservation of useful plant species complements the rural livelihood inhabiting the rugged and remote mountains of Far-Western Nepal. 
Key words: Api Nampa Conservation Area, Diversity, Darchula, Ethnobotany, Seabuckthorn.

\section{Background}

Nepal is ranked at around $25^{\text {th }}$ position in the global context and $11^{\text {th }}$ in the continental scale of biological diversity richness (BPP 1995; CBD 1997). Darchula is the Far-western mountainous district of the country, bordered with China at north and India at west. The district is famous for biodiversity and tourism, yet the resources are untapped because of the limited access. Moreover, the mountainous districts are very sensitive to climate change and curtailed by land-use and land cover change (Rimal et al. 2019) and are the least studied (Eriksson et al. 2009; Elliott 2012; Bhattarai et al. 2014).

Darchula district is one of the most inaccessible and underdeveloped areas of Nepal and faces numerous conservation and development challenges (Kunwar et al. 2017). The district with 233,700 ha area with transhimalayan and mountain geography has facilitated the strengthening of unique biodiversity and indigenous knowledge of plant use (Chaudhary et al. 2010) and an array of forest types (such as moist subtropical broadleaf to temperate oak forests) and alpine scrubs of conifers, Ephedra, Juniper, Rhododendron, Hippophae, and highaltitude pastures (Zomer \& Oli 2011; Elliott 2012, Ghimire et al. 2021). The rugged terrain, geographic heterogeneity, and over harvesting of useful plants in the district (Kunwar et al. 2012; Kunwar et al. 2015) pose a serious threat to sustainable ecosystems with implications for future biodiversity and human development (Uddin et al. 2015). The harsh climate, poor accessibility, marginality, and high level of poverty manifest high dependency on natural resources leading to over-exploitation (Roy et al. 2009). Rush collection for quick economic return also led the plant resources vulnerable (Pal 2009; Dadal 2010).

With the gradual worsening quality of environment and the overriding poverty, locally available and useful plants pose a hope for future. People use locally available medicinal plants for their livelihood and primary health care as development, modern and health care facilities are limited in rural remote villages. Collection of medicinal plants and their uses is still persistent with some adaptation (Kutal et al. 2021). Hippophae has attracted a great deal of attention because of its concentrated ecological, medicinal, and socioeconomic benefits. Darchula district is rich in Hippophae species (commonly called as Seabuckthorn, locally known as Chungo) (Kunwar et al. 2018). However, the studies regarding the richness, diversity, distribution, usefulness, and conservation of Seabuckthorn are scare in the district. Topographic features of the district such as slope gradients, aspect, and elevation largely play a major role in structuring composition of plants (Holland \& Steyne 1975). The present paper aims to analyze distribution, composition, usefulness, and conservation of flowering plants including Hippophae in ANCA and its vicinity in Darchula district, Far Western Nepal.

\section{Materials and Methods}

\section{Study area}

Api Nampa Conservation Area (ANCA) and its vicinity were selected as a study area for this study. The ANCA lies in the north-west Himalayan region of Nepal and lies in Darchula district. It lies at latitude of 29 $50^{\prime} 28^{\prime \prime} \mathrm{N}$ and longitude of $80^{\circ} 31^{\prime} 43^{\prime \prime}$. The climate is upper tropical, temperate to alpine. Above 3,000 m elevation, most of the area is ecologically sub-alpine or highland alpine region (Poudeyal et al. 2019). Cold and dry climate exists in the high alpine valleys just north of the southern arm of the Himalaya that cuts across the bottom of ANCA. The average maximum temperature is $18.6^{\circ} \mathrm{C}$ and minimum temperature goes below $0^{\circ} \mathrm{C}$. Most precipitation falls between May and September (Chaudhary et al. 2010). The dominant plant species are Alnus nepalensis, Artemisia gmelini, Cassiope fastigiata, Elaeagnus parvifolia, Girardiania diversifolia, Heracleum wallichii, Hippophae salicifolia, Ilex excelsa, Juglans regia, Juniperus indica, Pinus roxburghii and Rhododendron arboreum (Subedi et al. 2020).

Sampling was conducted in Api Nampa Conservation Area (ANCA) and its northern and eastern sides. Eastern ANCA was sampled as a protected, government managed site whereas the northern side of ANCA is community managed. The northern area of the district is ruderal, bare and dry due to steep slope angles and mostly covered by snow in most of the months in a year (Anonymous 2010; Kunwar et al. 2018). Transhumance is still persistent in Darchula. People live 6 months in northern Darchula (> 3000 masl) in the summer and then descend to the lowland (Khalanga) for the rest of the year (Manzardo 1977). 


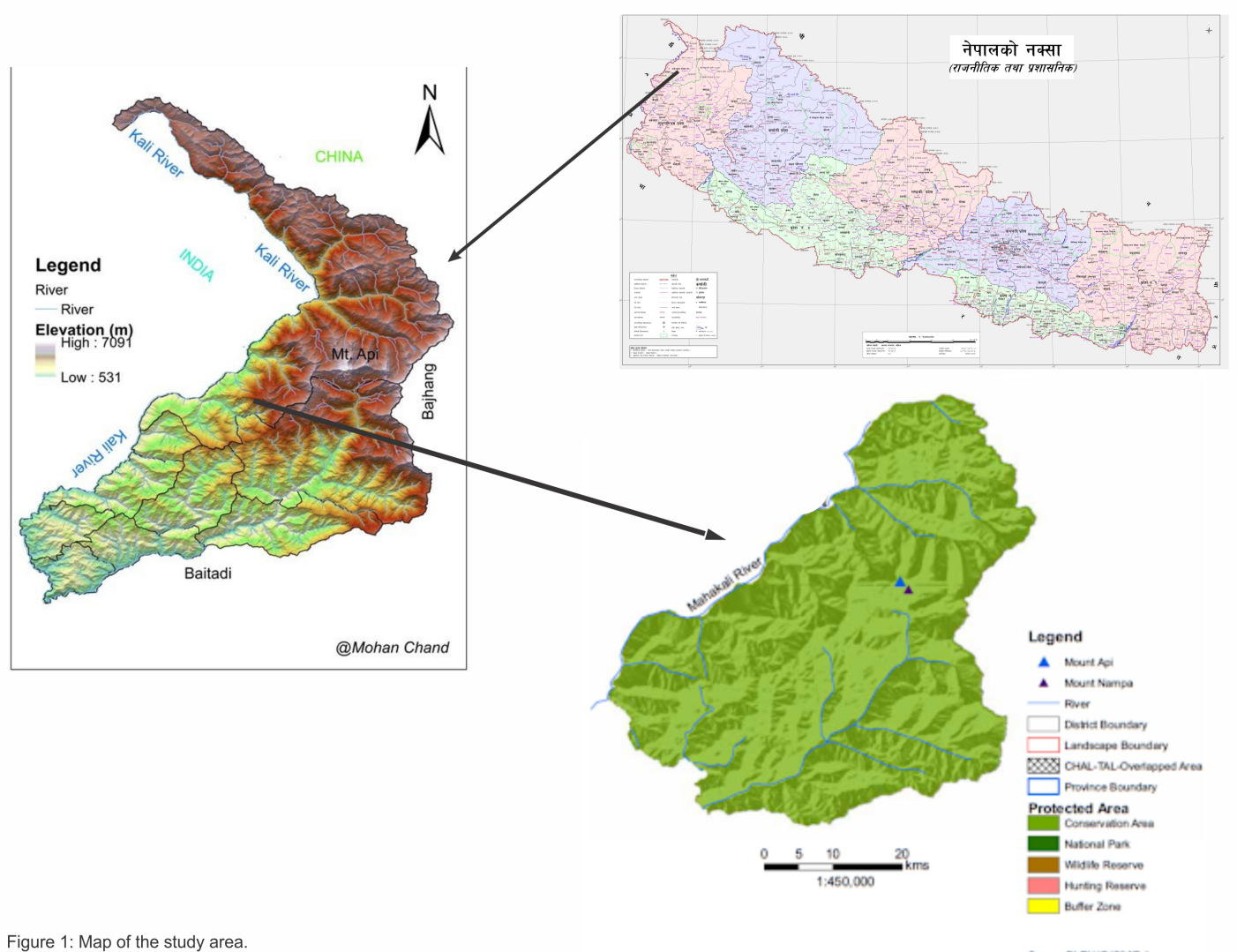

Figure 1. Map of the study area

\section{Field visits and ecological study}

Fieldwork for primary and qualitative and quantitative data collection was carried out twice between July 2019 and July 2020. Each fieldwork was lasted between 20-25 days. During the field visits, the data and information regarding composition of plant species, natural habitat, indigenous uses, and local conservation measures were collected. Plant samples were collected for voucher records and ethno-ecological studies. A total of 20 quadrats each measuring $10 \mathrm{~m} \times 10 \mathrm{~m}$ size were laid following stratified random sampling following Misra (1968). Ecological traits such as distribution, frequency, density, and Important Value Index (IVI) were studied following Curtis \& McIntosh (1951) and Zobel et al. (1987).

\section{Ethno-ecological survey and data analyses}

To assess the distribution of plant use knowledge, a total of 20 respondents, 10 from each site, age ranged between 45 years and 75 years including 15 men and 5 women were randomly interviewed following Kunwar et al. (2019). The name of useful species and use, along with the distribution of the species, availability and mode of application was sought in the interview. A semi-structured questionnaire was used for interview and supplementary information was collected through informal meetings (Putnam 1975). While pursuing informal meeting and questionnaire surveys, information of vernacular names and dominant and most useful species as well as conservation of species was collected. The collected information was compared with the published literature (Bhattarai \& Ghimire 2006; Rokaya et al. 2010; Bhatt \& Kunwar 2020, 2021; Graham et al. 2000; Wali et al. 2019; Anonymous 2005; Pokharel et al. 2021; Kumar et al. 2002).

\section{Collection and Identification}

The plant species referred to be useful by respondents were collected, pressed, dried, mounted and preserved based on standard methods as given by (Forman \& Bridson 1989). Before preservation all the collected vouchers were examined and identified with the help literature (Hooker 1872; Hara et al. 1978, 1982; Hara \& Williams 1979; Grierson \& Long 1983; Press et al. 2000). Furthermore, the species were confirmed by comparing with herbarium specimens deposited at KATH (National Herbarium and Plant Laboratories, Godawari, Lalitpur, Nepal), TUCH (Tribhuvan University Herbarium, Department of Botany, Kirtipur, Kathmandu), and Department of Botany, Siddhanath Science Campus, Mahendranagar. All voucher specimens were deposited at Department of Botany, 
Siddhanath Science Campus, Mahendranagar. Scientific name of plants and their families were verified with referring to the plant list (http://www.theplantlist.org/).

\section{Results and Discussion}

Plant species composition

A total of 76 plant species were recorded under 33 families and 62 genera. The highest number of genera belongs to Rosaceae ( 6 genera) and Asteraceae ( 6 genera). Similarly, highest number of species belongs to Asteraceae ( 8 species) (Fig. 2). The dominant families were Pinaceae, Rosaceae, Poaceae, Ericaceae and Asteraceae. The higher numbers of dominant species were recorded at protected site. Such type of species composition was consistent to with the findings of Bhatt and Kunwar (2020) at two different study sites in Kanchanpur, Nepal. The highest number of species occurred by the Asteraceae ( 8 species) family and least number was occurred by Juglandaceae family ( 1 species). The present composition of the dominant family agreed with the findings of Kunwar et al. (2020) and Subedi et al. (2020) in the same district. The highest density of the species occupied by Hippophae salicifolia (4) and lowest density occupied by Anaphalis contorta (0.2). The result is consistent with earlier studies carried from the same areas as the studies reported Hippophae as one of the common species in ANCA, Darchula (Thapa 2017; Kunwar et al. 2020; Subedi et al. 2020). The greater density of the species in area indicated that the elevational range 2000 to $4500 \mathrm{~m}$ is a good repository of Hippophae. The distribution pattern of the species contributed 41 (54.67\%) were as trees, 20 (26.67\%) herbs and 15 (20\%) shrubs.

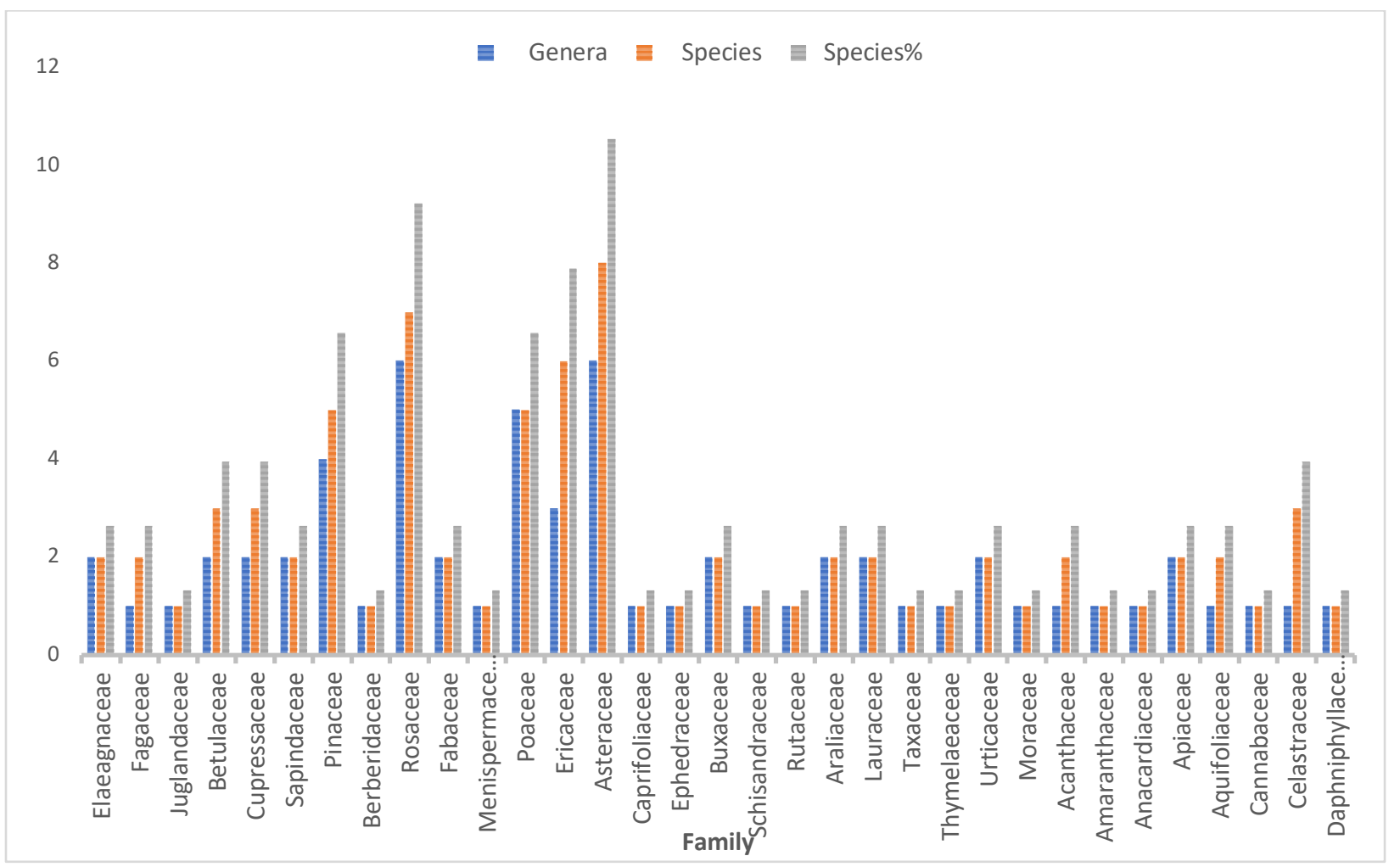

Figure 2. Composition of plant species on the basis of genera and species.

\section{Dominance and distribution of plant species}

A total of 12 plant species were reported as dominant species (IVI value $>9$ ) based on their recorded IVI value. The recorded dominant species were Alnus nepalensis, Artemisia gmelini, Cassiope fastigiata, Elaeagnus parvifolia, Girardiania diversifolia, Heracleum wallichii, Hippophae salicifolia, Ilex excelsa, Juglans regia, Juniperus indica, Pinus roxburghii and Rhododendron arboreum (Table 1). Out of the recorded dominant species, 8 were trees, 3 were shrubs and 1 species was herb. Over $50 \%$ species were tree species, contrasting to the findings of Kunwar et al. (2019) however, conforms to findings of DNPWC (2019). A total of 383 genera were reported from high altitude areas of Darchula, however, the Hippophae was underreported (Elliot 2012). 
Table 1 Dominant plant species in the study area.

\begin{tabular}{|l|l|l|l|}
\hline Name of plants & Dominant Families & $\begin{array}{l}\text { Importance Value Index } \\
\text { (IVI) }\end{array}$ & $\begin{array}{l}\text { Study } \\
\text { sites* }\end{array}$ \\
\hline Alnus nepalensis D. Don & Betulaceae & 14.29 & 1 \\
\hline $\begin{array}{l}\text { Artemisia gmelinii Webb ex } \\
\text { Stechmann }\end{array}$ & Asteraceae & 9.90 & 1,2 \\
\hline Cassiope fastigiata (Wall.) D.Don & Ericaceae & 9.90 & 1 \\
\hline Elaeagnus parvifolia (Wall.ex Royle) & Elaeagnaceae & 11.14 & 1,2 \\
\hline Girardiania diversifolia (Link) Friis & Urticaceae & 11.14 & 1 \\
\hline Heracleum wallichii DC. & Apiaceae & 9.90 & 1 \\
\hline Hippophae salicifolia L. & Elaeagnaceae & 26.95 & 1,2 \\
\hline Ilex excelsa (Wall.) Hook. f. & Aquifoliaceae & 12.45 & 1,2 \\
\hline Juglans regia L. & Juglandaceae & 12.45 & 1,2 \\
\hline Juniperus indica Bertol. & Cupressaceae & 14.29 & 1,2 \\
\hline Pinus roxburghii Sarg. & Pinaceae & 9.64 & 1 \\
\hline Rhododendron arboreum Sm. & Ericaceae & 11.14 & 1,2 \\
\hline
\end{tabular}

Total 76 plant species were recorded in two different study sites of ANCA, Darchula district. Of total, 60 (78.94\%) plant species were recorded from protected site and 37(48.68\%) plants species were from site north of ANCA. From the total species, 21 (27.63\%) were common in both sites (Annex 1). Out of the total plant species the highest density (4) individuals per meter square was occupied by the Hippophae salicifolia and minimum (0.2) was covered by Anaphalis contorta. Similarly, the highest IVI (26.95) was occupied by the species Hippophae salicifolia and minimum IVI (2.37) was occupied by Daphne papyraceae. The observed data proved that the ANCA of Darchula district is dominated by Hippophae salicifolia (Annex 1).

The study area is rich in biodiversity because the people of this area showed a large repertoire of knowledge that helps them determine different plant use strategies in conjunction with ecology, culture, and geography. This knowledge is the result of the area's biodiversity, deep cultural importance of using local endemics and the compliance of using local resources in reference to the geo-ecological constraints. Geo-ecological constraints and limited accessibility in the district led the overexploitation of local resources (Heim \& Gansser 1939; Manzardo 1977). Thus, the local availability of a plant is linked to its relative importance to a given community (Kunwar et al. 2018).

In comparative assessment, the community-managed area northern part of ANCA has a lower density of plants due to intensive use of plants and land use change interventions. Because of the steep slope and fragile geology in the northern side, forest degradation is serious and further vegetation loss is anticipated (Uddin et al. 2015). The harsh climate, poor accessibility, marginality, and high level of poverty manifest high dependency on natural resources leading to over-exploitation (Roy et al. 2009). Rush collection for quick economic return also led the plant resources vulnerable (Pal 2009; Dadal 2010). Fuel wood, fodder, and medicinal plant collection, summer grazing and climate change are major drivers impacting the ecology and biodiversity of the area. Their socioecological information and their interdependencies scale a better strategy for management to maintain sustainable development and biodiversity conservation in the limited access areas (Kunwar et al. 2019).

\section{Hippophae salicifolia (Seabuckthorn in Darchula)}

As evident from the ecological findings, Darchula is one of those districts where $H$. salicifoilais abundantly found. Hippophae is the native plant of the mountain region of Nepal and the species is found within the altitudes ranging approximately from $1800 \mathrm{~m}$ to $4500 \mathrm{~m}$ (TISC 2001) and has been reported from more than 25 mountain districts like: Baglung, Darchula, Dolakha, Dolpa, Humla, Jajarkot, Jumla, Kaski, Manang, Mugu, Mustang, Ramechhap, Rasuwa, Solukhumbu, Taplejung etc. (Vaidya 1999; Gupta et al. 2000; Baral 2002; Ansari 2003). Seabuckthorn distributes throughout the country in the high mountains. However, the main area of distribution is Northwest Nepal where the ecological and physiographical conditions are favorable. National Herbarium and Plant Laboratories (KATH), Godavari has specimens of three species of Hippophae, namely, H. salicifolia, H. tibetana, and H. rhamonoides. However, only former 2 species are reported to be extensively present in Northwestern and central mountainous districts of Nepal (Nepal et al. 2001). The species has long been using in the mountainous districts of Nepal for various purposes. For the farmers living in the mountains, it offers the opportunity to maintain a 
sustainable livelihood-providing healthy foods, variety of medicines and protecting their land from soil erosion (Lu 1992; Ansari 2003).

\section{Economic Botany of Hippophae}

Hippophae salicifolia is one of the most available plants in the study area. As the ecological apparency hypothesis initially proposed by Feeny (1976) inferred, the locally available plants are frequently consumed for local livelihood. Local people earn money by selling the juice, firewood of Hippophae salicifolia that helps in the economic development of local people in rural areas. The leaves and branches are also used as fodder, litter, and firewood collection (Rajchal 2008). Along with traditional uses, some new ones, such as condensed juice, mixed juice, candied fruits, cheese, butter, tea and health protection drinks are also being produced at local scale. In the Hindu-Kush Himalaya region, plant biomass is the most important source of energy (Bhattarai et al. 2004; ICIMOD 2006). It has proved to be a popular green energy plant because of its quality biomass and good source of firewood.

Hippophae salicifolia is one of the unique features of the study area where local people use the juice of fruit of this species for medicinal and food value, relief from hotness and use in winter by mixing it with boiled water for staying safe from common cold, health disorders such as headache, stomachache, skin problems, dysentery, cough, weakness and in reproductive health problems.

Local people use the juice of fruit for medicinal and food value because its juice is highly beneficial for human health. They use its juice in hot climate for getting relief from hotness and use in winter by mixing it with boiled water for staying safe from common cold. It is also used in high fever, brings relief from pain, and provides freshness. Juice of its fruit has been used in many other health disorders such as headache, stomachache, skin problems, dysentery, cough, weakness and in reproductive health problems. The comparative analysis of ethnomedicinal values in the study area are compared with the earlier studies (Anon 2005; Pokharel et al. 2021; Kumar et al. 2002; Vaidya 1999; Rongsen 1992) and presented in Table 2. The dependencies of local people on ethnomedicine in both the study sites were less similar.

Table 2. Comparative analysis of medicinal values of Hippophae salicifolia in the study area.

\begin{tabular}{|c|c|}
\hline $\begin{array}{l}\text { Ethnomedicinal use records in } \\
\text { the present study }\end{array}$ & Earlier reports of ethnomedicine with references \\
\hline Used as source of vitamin C. & Used as source of ascorbic acid (Rosch 2004). \\
\hline $\begin{array}{l}\text { Used as source of flavonoids and } \\
\text { the oils. }\end{array}$ & $\begin{array}{l}\text { Used as different sources of flavonoids and the oils (Li \& Schroeder } \\
\text { 1996). }\end{array}$ \\
\hline $\begin{array}{l}\text { Effective against skin problems, } \\
\text { cardiovascular diseases, and } \\
\text { immune system support. }\end{array}$ & $\begin{array}{l}\text { Effective against, cardiovascular diseases, mucosa injuries, skin } \\
\text { problems, cancer, and immune system support (Graham et al. 2000; } \\
\text { Wali et al. 2019). }\end{array}$ \\
\hline $\begin{array}{l}\text { Used in burns, bedsores, eczema, } \\
\text { etc. }\end{array}$ & $\begin{array}{l}\text { Externally used to treating a wide variety of skin damage, burns, } \\
\text { bedsores, eczema and radiation injury, antioxidant, cancer, } \\
\text { cardiovascular, immune system, skin, and other treatments including } \\
\text { cosmetic uses (Anon 2005; Pokharel et al. 2021). }\end{array}$ \\
\hline Used as anticancerous. & $\begin{array}{l}\text { It has been estimated that } 30-40 \% \text { of all cancers can be prevented by } \\
\text { lifestyle and dietary measures alone (WCRF/AICR 1997). }\end{array}$ \\
\hline Used as drugs. & $\begin{array}{l}\text { Drug metabolizing, detoxifying and antioxidant enzymes are } \\
\text { important cellular defenses against carcinogenic (Goel et al. 2003; } \\
\text { Kumar et al. 2002). }\end{array}$ \\
\hline $\begin{array}{l}\text { Used as healing of wounds and } \\
\text { dermatitis. }\end{array}$ & $\begin{array}{l}\text { The oil from the pulp/peel of berries is rich in palmitoleic acid and } \\
\text { oleic acid helpful for treating burns, healing wounds and skin } \\
\text { diseases, such as atopic dermatitis (Kumar et al. 2002). }\end{array}$ \\
\hline Used as oxidative processes. & $\begin{array}{l}\text { Used to free radical-mediated oxidative processes contribute to } \\
\text { atherogenesis (Eccleston et al. 2002; Ivanov \& Nikitina 1973). }\end{array}$ \\
\hline $\begin{array}{l}\text { Juice of fruits used against } \\
\text { gastritis. }\end{array}$ & Juice of fruits used against intestinal disorder (Pokharel et al. 2021). \\
\hline $\begin{array}{l}\text { Used against foul smell from the } \\
\text { mouth. }\end{array}$ & $\begin{array}{l}\text { Used as remedy vomiting, and also chewed to remove foul smell } \\
\text { from the mouth (Maity et al. 2004). }\end{array}$ \\
\hline Used against vomiting. & To remedy vomiting and as appetizer (Gairola et al. 2014) \\
\hline
\end{tabular}




\begin{tabular}{|l|l|}
\hline $\begin{array}{l}\text { Fruits are used for jaundice, pain, } \\
\text { cough, constipation. }\end{array}$ & $\begin{array}{l}\text { Fruits are used in skin diseases, as tooth pain reliever, killing warms, } \\
\text { stomach disorders, removal of teeth staining (mixed with ash), in } \\
\text { menstrual irregularity, in swelling \& muscular pain, for cough \& cold, } \\
\text { blood pressure, Jaundice, to control dysentery, asthma, and to join } \\
\text { broken and damaged parts of domestic animals. Other uses of the } \\
\text { plant are to cure of poison effects, to high altitude sickness, and to } \\
\text { lung troubles and constipation (Vaidya 1999). }\end{array}$ \\
\hline $\begin{array}{l}\text { Leaves are used as herbal tea and } \\
\text { cure tuberculosis. }\end{array}$ & $\begin{array}{l}\text { Leaf is applying as herbal tea and to be believed to cure tuberculosis. } \\
\text { The concentrated juice is said to be good medicine for those children } \\
\text { who cannot speak in due time (Vaidya 1999; Rongsen 1992). }\end{array}$ \\
\hline
\end{tabular}

\section{Pharmacolgical uses of Hippophae}

Hippophae possesses thorny berry which is a very rich source of vitamins and is called treasure of bio-activity substance because of its over 190 bio-active substances possessing unique medicinal properties (Maertz 2006). The most important pharmacological function of the plant oil is in diminishing inflammation, disinfecting bacteria, relieving pain, and promoting regeneration of tissue. The species has been shown to have a potent antioxidant activity, mainly attributed to its flavonoids and vitamin C content (Rosch 2004). Both the flavonoids and the oils have several potential applications (Li \& Schroeder 1996). The berries seem to have preventive effects against, cardiovascular diseases, mucosa injuries, skin problems, cancer, and immune system support (Graham et al. 2000; Wali et al. 2019). External uses include treating a wide variety of skin damage, burns, bedsores, eczema and radiation injury, antioxidant, cancer, cardiovascular, immune system, skin and other treatments including cosmetic uses (Anonymous 2005; Pokharel et al. 2021).

\section{Conclusions}

A total number of 76 plant species including Hippophae salicifolia were recorded under 33 different families and 62 genera. Over 50\% species were recorded as trees which indicated that trees were common in the study area. Government-managed protected site had greater number of plant species as compared to the communitymanaged rangeland. Intensive use of plants and land use change interventions made the community-managed area less diversified and enriched in plant species. As the Hippophae salicifolia was densely populated and distributed in and around the ANCA, the species has frequently been used for curing several ailments, nutritional values, and for producing food and cosmetics. The species with multiple uses are at the verge of extinction because of persistent use, human disturbance, and land use change. Conservation of useful plant species complements the rural livelihood inhabiting the rugged and remote mountains of Far Western Nepal.

\section{Declarations}

List of Abbreviation: Not applicable.

Ethics approval and consent to participate: Permission for data collection was obtained from the chairperson of ANCA and oral agreements were obtained from local informants about the aims and objectives of the study prior to interviews and all field data were collected through their oral consents. No further ethics approval was required. Consent for publication: All the data of paper includes original so consent for publication is not required. Availability of data and materials: The data are available from the authors upon request.

Competing interests: The authors declare that they have no competing interest among them.

Funding: This research work is self-funded and didn't receive any grant from formal and informal funding agencies. Authors' contribution: DJ carried out fieldwork, collected data and identified plant species. RMK and MDB analyzed data and helped to prepare the draft for the manuscript. All authors equally participated in writing and giving feedback on the manuscript and approved the final version of the manuscript.

\section{Acknowledgments}

Author DJ is thankful to Head of Department of Botany, Siddhanath Science Campus, Tribhuvan University Mahendranagar, Nepal, for providing facilities and support throughout the study period. The authors also would like to thank the local people for their kind cooperation in sharing the valuable information.

\section{Literature cited}

Anonymous. 2005. Sea buckthorn Research. Accessed on http://www.seabuckthorn research.com, 2007-02-25. 
Anonymous. 2010. Annual Report 2009-2010, Department of National parks and Wildlife Conservation (DNPWC), Government of Nepal, Kathmandu, Nepal.

Ansari AH. 2003. Sea buckthorn (Hippophae Linn. ssp) -A Potential Resource for Biodiversity Conservation in Nepal Himalayas. International Workshop on Underutilized Plant Species. 06- 08 May 2003, Leipzig, Germany.

Baral SR. 2002. Present Status and Opportunity of Developing Seabuckthorn (Hippophae Linn. spp) in Nepal: A Review. Banko Janakari,12(2):33-41.

Bhatt MD, Adhikari YP, Kunwar RM. 2021. Ethnobotany of Weeds in Kanchanpur District, Far-Western Nepal. Ethnobotany Research and Applications 1:19. doi: 10.32859/era.21.19.1-19.

Bhatt MD, Kunwar RM. 2020. Distribution pattern and ethnomedicinal uses of plants in Kanchanpur district, FarWestern Nepal. Ethnobotany Research and Applications, 20:14 doi: 10.32859/era.20.14.1-21.

Bhattarai KR, Ghimire M. 2006. Commercially important medicinal and aromatic plants of Nepal and their distribution pattern and conservation measure along the elevation gradient of the Himalayas. Banko Jankari 16:313.

Bhattarai KR, Vetaas OR, Grytnes JA. 2004. Relationship between plant species richness and biomass in arid subalpine grassland of the central Himalayas, Nepal. Folia Geobotanica 39:57-71.

Bhattarai P, Bhatta KP, Chhetri R, Chaudhary RP. 2014. Vascular plant species richness along gradient of the Karnaliriver, Nepal Himalaya. International Journal of Plant Animal and Environmental Science 4:114-126.

Biodiversity Profile Project (BPP). 1995. Biodiversity profile of the Midhills physiographic Zone. Technical Publication No. 13, Government of Nepal, Ministry of Forests and Soil Conservation and Government of the Netherlands, Ministry of Forest Affairs.

CBD. 1997. Nepal- Convention on Biological Diversity (CBD), Https://www.cbd.int_December.

Chaudhary RP, Shrestha KK, Jha PK, Bhatta K. 2010. Kailash Sacred Landscape conservation initiative feasibility assessment report-Nepal. International Center for Integrated Mountain Development, Kathmandu, p 207.

Curtis JT, McIntosh RP. 1951. An Upland Forest Continuum in the Prairie-Forest Border Region of Wisconsin. Ecology 31:476-496.

Dadal AS. 2010. The role of non-timber forest products in income generating activities: A case study of Yartsagunbu in Yerkot VDC of Darchula District. MS thesis, Central Department of Economics, Tribhuvan University, Nepal.

DNPWC. 2019. Biodiversity Profile of The Api Nampa Conservation Area, Nepal. Department of National Parks and Wildlife Conservation, Kathmandu, Nepal.

Eccleston C, Baoru Y, Tahvonen R, Kallio H, Rimbach GH and Minihane AM. 2002. Effects of an Antioxidant-Rich Juice (Seabuckthorn) on Risk Factors for Coronary Heart Disease in Humans. Journal of Nutritional Biochemistry 13(6):346-354.

Eriksson M, Xu J, Shrestha AB, Vaidya RA, Nepal S, Sandstrom K. 2009. The changing Himalayas: impact of climate change on water resources and livelihoods in the Greater Himalayas. Kathmandu: ICIMOD, p 23.

Elliott A. 2012. Botanical exploration of Darchula district, Far West Nepal. Scottish Rock Garden Club, Royal Botanic Garden Edinburgh, The University of Edinburgh, Edinburgh, UK, 35 pp.

Feeny PP. 1976.Plant apparency and chemical defense. In: Wallace JW, Manse RL (Eds.), Recent Advances in Phytochemistry. Plenum Press, New York, pp. 1-40.

Forman L, Bridson D. 1989. The Herbarium Handbook. Royal Botanic Gardens Kew, Great Britain.

Gairola S, Sharma J, Singh Bedi Y. 2014. A cross-cultural analysis of Jammu, Kashmir and Ladakh (India) medicinal plant use. Journal of Ethnopharmacology 155:925-986.

Ghimire SK, Subedi CK, Magar S, Adhikari M, Pandey TR. 2021. Flora of Kailash Sacred Landscape, Nepal. Research Centre for Applied Science and Technology, Tribhuvan University, Nepal.

Goel HC, Kumar PI, Samanta N, Rana SVS. 2003. Induction of DNA-Protein Cross-Links by Hippophae rhamnoides. Implication in Radiation Protection and Cytotoxicity. Molecular Cellulose Biochemistry 245:57-67. 
Graham JG, Quinn ML, Fabricant DS, Farnsworth NR. 2000. Plants used against cancer-an extension of the work of Jonathan Hartwell. Journal of Ethnopharmacology 73:347-77.

Grierson AJ, Long DG. 1983. Flora of Bhutan, including a record of plants from Sikkim. Vol. 1, Part 1 and 2. Royal Botanic Garden.

Gupta VN, Nepal VP, Ghimire S, Subedi CK, Adhikari K. 2000. An Ecological Assessment of Sea buckthorn (Hippophae spp) Resource in North-West Nepal. Tree Improvement and Silviculture Component, Hattisar, Kathmandu, Nepal.

Hara H, Stearn WT, Williams LHJ. 1978. An enumeration of the flowering plants of Nepal; a joint project of the British Museum (Natural History) and the Univ. of Tokyo-v. 1: (Gymnospermae and Angiospermae (Monocotyledones)), British Museum of Natural History, London.

Hara H, Stearn WT, Williams LHJ. 1982. An enumeration of the flowering plants of Nepal. British Museum (Natural History), London.

Hara H, Williams LHJ. 1979. An enumeration of the flowering plants of Nepal. British Museum of Natural History, London.

Heim A, Gansser A. 1939. The Throne of the Gods. The McMillan Co., York, New York, pp. 233.

Holland PG, Steyne DG. 1975. Vegetation responses to latitudinal variations in slope angle and aspect. Journal of Biogeography 2:179-183. doi: 10.2307/3037989.

Hooker JD. 1872. The Flora of British India Vol. 1. The Flora of British India, Vol. 1.

ICIMOD. 2006. Sea buckthorn: A Multipurpose Plant Species for Fragile Mountains. Sustainable Options for the Mountains Best Practices and Appropriate Technologies. Accessed on http://www.icimod.org/sus_options/bp_soil.htm. 2006-02-25.

Ivanov VN and Nikitina LP. 1973. Effect of Sea Buckthorn Oil on Certain Indices of Lipid Metabolism in Experimental Atherosclerosis. Vopr Pitan 7:36-37.

Kumar IP, Namita S, Goel HC. 2002. Modulation of chromatin organization by RH-3, a preparation of Hippophae rhamnoides, a possible role in radio protection. Molecular and Cellular Biochemistry 238:1-9.

Kunwar RM, Mahat L, Sharma L, Shrestha KP, Kominee, H and Bussmann RW. 2012. Underutilized plant species in Far West Nepal. Journal of Mountain Science 9:589-600.

Kunwar RM, Acharya RP, Chowdhary CL, Bussmann RW. 2015. Medicinal plant dynamics in indigenous medicines in Farwest Nepal. Journal of Ethnopharnacology 163:210-219.

Kunwar R, Hindle T, Rimal B. 2017. Forest Cover and Land-use Change in Rural Mountain District Darchula of Farwestern Nepal. The Florida Geographer 49. https://journals.flvc.org/flgeog/article/view/106161/101789

Kunwar RM, Fadiman M, Cameron M, Bussmann RW, Thapa-Magar KB, Rimal B, Sapkota P. 2018. Cross-cultural comparison of plant use knowledge in Baitadi and Darchula districts, Nepal Himalaya. Journal of Ethnobiology and Ethnomedicine 14(1):1-17.

Kunwar R, Shrestha K, Malla S, Acharya T, Sementeli A, Kutal D, Bussmann RW. 2019. Relation of medicinal plants, their use patterns and availability in the lower Kailash Sacred Landscape, Nepal. Ethnobotany Research and Applications 18:6.

Kunwar RM, Fadiman M, Thapa S, Acharya RP, Cameron M, Bussmann RW. 2020. Plant use values and phytosociological indicators: implications for conservation in the Kailash Sacred Landscape, Nepal. Ecological Indicators 108:105679.

Kutal HD, Kunwar RM, Uprety Y, Adhikari YP, Bhattarai S, Adhikari B, Kunwar LM, Bhatt MD, Bussmann RW. 2021. Selection of medicinal plants for traditional medicines in Nepal. Journal of Ethnobiology and Ethnomedicine 17 (1):1-1.

Li TSC, Schroeder WR. 1996. Sea buckthorn (Hippophae rhamnoides): A Multipurpose Plant, Horticultural Technology, 6(4): 370-378. 
Lu R. 1992. Sea buckthorn - A: Multipurpose Plant for Fragile Mountains. International Center for Integrated Mountain Development ICIMOD. Occasional Paper No. 20. Kathmandu, Nepal.

Maertz J. 2006. Sea buckthorn Nutritional Properties: Meet the Little Orange Berry from the Himalayas that's Interesting in Your Well-being. Sibu: The Sea buckthorn Company. http://www.mysibu.com, 2006-08-25.

Manzardo AE. 1977. Ecological constraints on trans-Himalayan trade in Nepal. Contrib. Nepalese Studies 4(2):6381.

Maity D, Pradhan N, Chauhan AS. 2004. Folk uses of some medicinal plants from North Sikkim. Indian Journal of Tradituinal Knowledge 3(1):66-71.

Misra R. 1968. Workbook ecology. Oxford and IBH Publishing Co., New Delhi, India.

Nepal V, Poudyal DP, Subedi CK, Adhikari K, Dhakal LP, Gupta VNG. 2001. An ecological assessment of Seabuckthorn (Hippophae spp.) Resource in Manang and Mustang districts of Nepal. In proceeding of the international symposium on the Himalayan Environments, pp. 72-81.

Pal TB. 2009. A study on Yartsagumba collection in Darchula district of Nepal. MS thesis, Central Department of Economics, Tribhuvan University, Nepal.

Pokharel YR, Kunwar RM, Bussmann RW, Paniagua-Zambrana NY, Abbasi AM. 2021. Hippophae rhamnoides L. ssp. turkestanica Rousi, Ethnobotany of the Himalayas, Ethnobotany of Mountain Regions, https://doi.org/10.1007/9783-030-57408-6_117.

Poudeyal MR, Meilby H, Shrestha BB, Ghimire SK. 2019. Harvest effects on density and biomass of Neopicrorhiza scrophularïflora vary along environmental gradients in the Nepalese Himalayas. Ecology and Evolution 9:77267740 .

Press JR, Shrestha KK, Sutton DA. 2000. Annotated Checklist of the Flowering Plants of Nepal. The Natural History Museum, London.

Putnam AM. 1975. The Tea Shop as an Arena of Ethnic Interaction in Nepal. Contribution to Nepalese Studies 2:1117.

Rajchal R. 2008. Seabuckthorn (Hippophae salicifolia) management for the upliftment of local livelihood in Mustang district. Rongsen, L. 1992. Seabuckthorn- a multipurpose plant for fragile mountains. ICIMOD occasional paper no: 20. International Center for Integrated Mountain Development, Kathmandu.

Rimal B, Keshtkar H, Sharma R, Stork N, Rijal S, Kunwar R. 2019. Stimulating urban expansion in a rapidly changing landscape in eastern Tarai, Nepal. Environmental Monitoring and Assessment 191 4):1-4.

Rokaya MB, Munzbergovaa Z, Timsina B. 2010. Ethnobotanical study of medicinal plants from the Humla district of western Nepal. Journal of Ethnopharmacology,130:485-504, doi: 10.1016/j.jep.2010.05.036.

Rongsen L. 1992. Sea buckthorn: A multipurpose plant species for Fragile Mountains. ICIMOD occasional paper no. 20, Kathmandu, Nepal, pp.5-20.

Rosch D. 2004. Structure-Antioxidant Efficiency Relationships of Phenolic Compounds and Their Contribution to the Antioxidant Activity of Sea buckthorn Juice,.Journal of Agricultural Food Chemistry 51(15):4233-4239.

Roy R, Schmidt-Vogt D, Myrholt O. 2009. Humla Development Initiatives for better livelihoods in the face of isolation and conflict. Mountain Research and Development 29(3):211-219.

Subedi CK, Rokaya MB, Münzbergová Z, Timsina, Gurung J, Chettri N, Baniya CB, Ghimire SK, Chaudhary RP. 2020. Vascular plant diversity along an elevational gradient in the Central Himalayas, western Nepal. Folia Geobotanica. doi: 10.1007/s12224-020-09370-8.

Thapa S. 2017.Richness and Distribution Pattern of Palatable and Unpalatable Plant Species in Subalpine-Nival Gradient in Chameliya Valley, North-West Nepal. MSc Thesis, 69 p, submitted to Tribhuvan University, Kathmandu, Nepal.

TISC 2001. Proceeding of Workshop on Ecology and Distribution of Sea buckthorn (Hippophae spp.) Resource in Northwest Mountains of Nepal. HMG/DANIDA NARMSAP, Tree Improvement and Silviculture Component, Hattisar, Kathmandu. 
Uddin K, Shrestha HL, Murthy MSR, et al.2015. National land cover database for Nepal. Journal of Environmental Management 148:82-90. doi: 10.1016/j.jenvman.2014.07.047

Vaidya BB. 1999. Seabuckthorn Appropriate for Himalayan Region. HMGT/DANIDA, TISC, Nepal.

Wali R, Rahman K, Raja NI, Qureshi R, Bussmann RW, Mashwani ZUR. 2019. A quantitative medico botanical expedition of Fairy Meadows National Park, Diamir, GilgitB altistan, Pakistan. Ethnobotany Research and Appl.ications 18:35. doi:10.32859/era.18.35.1-30.

WCRF/AICR. 1997. Food, Nutrition and the Prevention of Cancer: A Global Perspective. World Cancer Research Fund / American Institute for Cancer Research.

Zobel DB, Jha PK, Behan ML, Yadav URK. 1987. A Practical Manual for Ecology. Ratna Book Distributor, Kathmandu, Nepal.

Zomer RJ, Oli KP. 2011. Kailash sacred landscape conservation initiative: feasibility assessment report. Kathmandu: ICIMOD, p 92, ISBN: 9789291152117.

Annex 1 . Showing distribution pattern with Density and IVI of plant species in the study area.

\begin{tabular}{|c|c|c|c|c|c|c|c|}
\hline \multirow[t]{2}{*}{ Family } & \multirow[t]{2}{*}{ Scientific name } & \multirow{2}{*}{$\begin{array}{l}\text { Local } \\
\text { Names }\end{array}$} & \multirow{2}{*}{$\begin{array}{l}\text { Life } \\
\text { span }\end{array}$} & \multicolumn{2}{|c|}{ Site 1} & \multicolumn{2}{|c|}{ Site 2} \\
\hline & & & & RD & IVI & RD & IVI \\
\hline Pinaceae & $\begin{array}{l}\text { Abies spectabilis (D. Don) } \\
\text { Spach }\end{array}$ & Talispatra & Tree & 2.38 & 7.73 & 1.48 & 4.74 \\
\hline Sapindaceae & Acer cappadocicum Gled. & Tilelo & Tree & 0.99 & 3.91 & - & - \\
\hline Sapindaceae & $\begin{array}{l}\text { Aesculus indica (Wall. ex } \\
\text { Cambess.) Hook }\end{array}$ & Paangar & Tree & - & - & 2.38 & 7.99 \\
\hline Betulaceae & Alnus nepalensis D. Don & Utis & Tree & 5.95 & 14.29 & - & - \\
\hline Amaranthaceae & Amaranthus blitum L. & Bethae & Herb & - & - & 1.19 & 4.84 \\
\hline Asteraceae & $\begin{array}{l}\text { Anaphalis contorta (D. Don) } \\
\text { Hook. f. }\end{array}$ & BukiPhool & Herb & 1.48 & 5.77 & 1.19 & 4.84 \\
\hline Asteraceae & Anaphalis nubigena DC. & Pearl & Herb & 1.48 & 5.07 & - & - \\
\hline Poaceae & $\begin{array}{l}\text { Andropogon munroi C.B. } \\
\text { Clarke }\end{array}$ & Banso & Herb & 2.97 & 7.60 & 1.19 & 4.84 \\
\hline Araliaceae & Aralia cachemiricaDecne & Bankhor & Herb & 1.48 & 4.74 & - & - \\
\hline Asteraceae & $\begin{array}{l}\text { Artemisia gmelini Webb ex } \\
\text { Stechmann }\end{array}$ & Ganaunepati & Shrub & 3.57 & 9.90 & 1.48 & 4.74 \\
\hline Asteraceae & $\begin{array}{l}\text { Artemisia indica (Wild.) } \\
\text { Yomogi }\end{array}$ & Titepati & Herb & 1.98 & 5.76 & - & - \\
\hline Fabaceae & Astragalus onobrychis L. & Milkvetch & Herb & 1.98 & 5.76 & - & - \\
\hline Berberidaceae & $\begin{array}{l}\text { Berberies asiatica Roxb. ex } \\
\text { DC. }\end{array}$ & Chutro & Shrub & - & - & 1.19 & 4.84 \\
\hline Betulaceae & $\begin{array}{l}\text { Betula alnoides Buch.-Ham. } \\
\text { ex D. Don }\end{array}$ & Lekhpainyu & Tree & 1.48 & 4.74 & - & - \\
\hline Betulaceae & Betula utilis D. Don & Bhojpatra & Tree & 1.48 & 4.74 & - & - \\
\hline Buxaceae & Buxus wallichiana Baill. & Papro & Tree & 0.99 & 3.73 & - & - \\
\hline Asteraceae & Carpesium nepalense Less. & PadkeGhas & Herb & 0.99 & 3.91 & - & - \\
\hline Ericaceae & $\begin{array}{l}\text { Cassiope fastigiata (Wall.) D. } \\
\text { Don }\end{array}$ & Phalu & Shrub & 3.57 & 9.90 & - & - \\
\hline Pinaceae & $\begin{array}{l}\text { Cedrus deodara (Roxb.) G. } \\
\text { Don }\end{array}$ & Deodar & Tree & 2.97 & 7.60 & 2.38 & 7.73 \\
\hline Cannabaceae & Celtisaus trails L. & Khadik & Tree & 2.38 & 7.73 & 1.48 & 4.74 \\
\hline Poaceae & Chrysopogon gryllus (L.) Trin. & Daphleghas & Herb & 0.99 & 3.91 & - & - \\
\hline $\begin{array}{l}\text { Menispermacea } \\
\text { e }\end{array}$ & Cocculuslauri folius DC. & Aadukolli & Shrub & - & - & 1.19 & 4.84 \\
\hline Apiaceae & $\begin{array}{l}\text { Cortiade pressa (D. Don) C. } \\
\text { Norman }\end{array}$ & Bajari & Herb & 1.48 & 4.74 & - & - \\
\hline
\end{tabular}




\begin{tabular}{|c|c|c|c|c|c|c|c|}
\hline Rosaceae & $\begin{array}{l}\text { Cotoneaster dammeri C.K. } \\
\text { Schneid. }\end{array}$ & Khareto & Shrub & 1.48 & 5.07 & - & - \\
\hline Cupressaceae & $\begin{array}{l}\text { Cupressus torulosa D. Don ex } \\
\text { Lamb. }\end{array}$ & Raj sallo & Tree & 1.48 & 5.07 & - & - \\
\hline Poaceae & $\begin{array}{l}\text { Cymbopogon distans (Nees } \\
\text { ex Steud.) W. Watson }\end{array}$ & $\begin{array}{l}\text { Malabar } \\
\text { geass }\end{array}$ & herb & 1.98 & 5.76 & - & - \\
\hline Thymelaeaceae & $\begin{array}{l}\text { Daphne papyraceae Wall. ex } \\
\text { G. Don }\end{array}$ & Baduwa & Shrub & 0.49 & 2.37 & - & - \\
\hline $\begin{array}{l}\text { Daphniphyllace } \\
\text { ae }\end{array}$ & $\begin{array}{l}\text { Daphniphyllum himalense } \\
\text { (Benth.) Müll.-Arg. }\end{array}$ & Rakchan & Tree & 1.98 & 5.91 & 1.19 & 4.84 \\
\hline Urticaceae & $\begin{array}{l}\text { Debregeasia salicifolia(D. } \\
\text { Don) Rendle }\end{array}$ & Tusaro & Shrub & 0.99 & 3.91 & - & - \\
\hline Fabaceae & $\begin{array}{l}\text { Desmodium heterocarpon } \\
\text { (L.) DC. }\end{array}$ & Chamleu & Shrub & 2.38 & 7.73 & 1.98 & 5.76 \\
\hline Asteraceae & Doronicum roylei DC. & & Herb & 2.97 & 7.60 & - & - \\
\hline Poaceae & $\begin{array}{l}\text { Drepanostachyum falctum } \\
\text { (Nees) Keng f. }\end{array}$ & Banso & Tree & 0.99 & 3.73 & - & - \\
\hline Asteraceae & Dubyaea hispida (D. Don) DC & $\begin{array}{l}\text { Leopards } \\
\text { bane }\end{array}$ & Herb & - & - & 1.19 & 4.84 \\
\hline Elaeagnaceae & $\begin{array}{l}\text { Elaeagnus parvifolia Wall. ex } \\
\text { Royle }\end{array}$ & Guyalo & Tree & 3.57 & 11.14 & 1.48 & 4.74 \\
\hline Ephedraceae & $\begin{array}{l}\text { Ephedra gerardiana Wall. ex } \\
\text { C.A. Meyer }\end{array}$ & Somlata & Shrub & 0.49 & 2.37 & - & - \\
\hline Celastraceae & Euonymus fimbriatus Wall. & Pahenlyath & Tree & 1.19 & 4.84 & 0.49 & 2.37 \\
\hline Celastraceae & Euonymus frigidus Wall & & Tree & - & - & 1.19 & 4.84 \\
\hline Celastraceae & Euonymus porphyreus Loes & Dandan & Tree & - & - & 2.76 & 6.38 \\
\hline Moraceae & Ficus nerrifolia Sm. & Dudhilo & Tree & 2.97 & 7.60 & - & - \\
\hline Urticaceae & $\begin{array}{l}\text { Girardianiadiversifolia (Link) } \\
\text { Friis }\end{array}$ & Sisno & Herb & 3.57 & 11.14 & & \\
\hline Araliaceae & Hedera nepalensis K. Koch & Belaghans & Herb & - & - & 0.99 & 3.91 \\
\hline Apiaceae & Heracleum wallichii DC. & Chetare & Herb & 3.57 & 9.90 & - & - \\
\hline Elaeagnaceae & Hippophae salicifolia L. & Sankhadhara & Tree & 14.29 & 26.95 & 9.90 & 18.49 \\
\hline Aquifoliaceae & Ilex dipyrena Wall & Setokharsu & Tree & 2.47 & 6.77 & - & - \\
\hline Aquifoliaceae & Ilex excels (Wall.) Hook. f. & Puwanle & Tree & 4.76 & 12.45 & 0.99 & 3.73 \\
\hline Juglandaceae & Juglansregia L. & Okhar & Tree & 4.76 & 12.45 & 2.38 & 7.73 \\
\hline Cupressaceae & Juniperus indica Bertol. & Dhupi & Tree & 5.95 & 14.29 & 0.99 & 3.73 \\
\hline Cupressaceae & $\begin{array}{l}\text { Juniperus squamata Buch.- } \\
\text { Ham. ex D. Don }\end{array}$ & Dhupi & Tree & 0.99 & 3.91 & - & - \\
\hline Asteraceae & $\begin{array}{l}\text { Ligulariaf ischeri (Ledeb.) } \\
\text { Turcz. }\end{array}$ & & Herb & 1.48 & 4.22 & 1.19 & 4.84 \\
\hline Caprifoliaceae & $\begin{array}{l}\text { Lonicera maackii (Rupr.) } \\
\text { Maxim. }\end{array}$ & & Shrub & 1.19 & 4.84 & 2.47 & 6.25 \\
\hline Ericaceae & $\begin{array}{l}\text { Lyonia ovalifolia (Wall.) } \\
\text { Drude }\end{array}$ & Angeri & Tree & - & - & 2.38 & 7.73 \\
\hline Lauraceae & $\begin{array}{l}\text { Neolitse apallens (D. Don) } \\
\text { Momiy. \& H. Hara }\end{array}$ & & Tree & 2.47 & 6.25 & 1.19 & 4.84 \\
\hline Lauraceae & $\begin{array}{l}\text { Perseaodor atissima (Nees) } \\
\text { Kosterm }\end{array}$ & Kaulo & Tree & - & - & 2.38 & 7.99 \\
\hline Pinaceae & Pinus roxburghii Sarg. & Khotesalla & Tree & 3.46 & 9.64 & - & - \\
\hline Pinaceae & Pinus wallichiana A.B. Jacks. & Gobresalla & Tree & 1.48 & 4.74 & - & - \\
\hline Rosaceae & Prinse piautilis Royle & Dhatelo & Shrub & 2.47 & 6.77 & - & - \\
\hline Rosaceae & Prunus cerasoides D. Don & Painyu & Tree & 2.97 & 7.60 & - & - \\
\hline Rosaceae & $\begin{array}{l}\text { Prunus nepalensis (Ser.) } \\
\text { Steud. }\end{array}$ & Arato & Tree & 1.48 & 4.74 & - & - \\
\hline Rosaceae & $\begin{array}{l}\text { Pyracantha crenulata (D. } \\
\text { Don) M. Roem. }\end{array}$ & Ghangaru & Shrub & 0.99 & 3.91 & - & - \\
\hline
\end{tabular}




\begin{tabular}{|c|c|c|c|c|c|c|c|}
\hline Rosaceae & Pyrus pasia L. & Mel & Tree & - & - & 1.19 & 4.84 \\
\hline Fagaceae & Quercus lanata Sm. & Banj & Tree & - & - & 1.98 & 5.90 \\
\hline Fagaceae & Quercus semecarpofolia Sm. & Kharsu & Tree & 1.48 & 4.74 & - & - \\
\hline Ericaceae & $\begin{array}{l}\text { Rhododendron anthopogon } \\
\text { D. Don }\end{array}$ & Sunpati & Shrub & 1.98 & 5.91 & - & - \\
\hline Ericaceae & $\begin{array}{l}\text { Rhododendron arboreum } \\
\text { Sm. }\end{array}$ & Laligurans & Tree & 3.57 & 11.14 & 1.48 & 4.74 \\
\hline Ericaceae & $\begin{array}{l}\text { Rhododendron barbatum } \\
\text { Wall. ex G. Don }\end{array}$ & Chimal & Tree & 2.38 & 7.73 & 0.49 & 2.37 \\
\hline Ericaceae & $\begin{array}{l}\text { Rhododendron } \\
\text { campanulatum D.Don }\end{array}$ & Gurans & Tree & 1.48 & 4.74 & - & - \\
\hline Buxaceae & $\begin{array}{l}\text { Sarcococca saligna (D. Don) } \\
\text { Müll-Arg. }\end{array}$ & Telparo & Shrub & - & - & 2.38 & 7.99 \\
\hline Schisandraceae & $\begin{array}{l}\text { Schisandra grandiflora (Wall.) } \\
\text { Hook. f. \& Thomson }\end{array}$ & Gofala & Herb & 2.38 & 7.73 & 0.99 & 3.73 \\
\hline Rosaceae & Sorbus lanata D. Don & Naalo & Tree & - & - & 2.38 & 7.73 \\
\hline Acanthaceae & Strobilanthes buteraea Nees & & Shrub & 0.49 & 2.37 & - & - \\
\hline Acanthaceae & $\begin{array}{l}\text { Strobilanthes tomentosa } \\
\text { (Nees) J.R.I. Wood }\end{array}$ & $\begin{array}{l}\text { Kangaraito } \\
\text { phool }\end{array}$ & Herb & 2.47 & 6.77 & - & - \\
\hline Taxaceae & Taxus contorta Griff. & Lauthsalla & Tree & 2.97 & 7.94 & - & - \\
\hline Poaceae & $\begin{array}{l}\text { Themeda anathera (Nees ex } \\
\text { Steud.) Hook. }\end{array}$ & Loonder & Herb & - & - & 1.19 & 4.84 \\
\hline Anacardiaceae & $\begin{array}{l}\text { Toxicodendron wallichii } \\
\text { (Hook. f.) Kuntze }\end{array}$ & Bhamkilo & Tree & 0.99 & 3.73 & - & - \\
\hline Pinaceae & $\begin{array}{l}\text { Tsuga dumosa (D. Don) } \\
\text { Eichler }\end{array}$ & Thingesalla & Tree & - & - & 2.38 & 6.03 \\
\hline Rutaceae & Zanthoxylum armatum DC. & Timur & Tree & 2.38 & 7.73 & 1.48 & 4.74 \\
\hline
\end{tabular}

